between Angmagsalik and Kangerdlugsuak and showed that detailed studies within this area would produce results of great value. Two further visits to East Greenland followed, first with Mikkelsen in 1932, and then the British East Greenland Expedition of 1935-36, organised and led by Wager himself. Between these two expeditions he was a climbing member of the 1933 Mount Everest Expedition and took part that year in the first assault on the summit from Camp VI, becoming one of the few to have climbed higher than 28,000 ft. During the Expedition he made a geomorphological study of the Arun River drainage pattern and its relationship to the rise of the Himalayas.

It is, however, for his work in Greenland that Prof. Wager has achieved wide distinction, and here the problems gave full scope for his broad interests. His work in this field covers such diverse subjects as the form and age of the Greenland Ice Cap, the Kap Dalton sedimentary series, the East Greenland dyke swarm and crustal flexure, the stratigraphy and tectonics of Knud Rasmussen Land and the petrology of the Skaergaard Intrusion. The latter work is perhaps the most detailed and closely reasoned account of differentiation in magma of basaltic composition in the literature, and has become a milestone in the development of igneous petrology. During the War he served with distinction in the photographic intelligence branch of the Royal Air Force. Since his appointment in 1944 to the chair of geology at Durham, Prof. Wager has entered the field of geochemistry and has completed a detailed study of the distribution of the minor elements in the strongly differentiated Skaergaard Intrusion. Since 1945 he has inspired a team of research workers at Durham to undertake the re-investigation of the classical area of the Tertiary igneous activity in Skye, and it is hoped that his departure will not unduly delay the completion of this work. Prof. Wager's distinction as a geologist, explorer and mountaineer has received wide recognition. He was awarded an Arctic Medal in 1933, a Leverhulme fellowship in 1935, the Mungo Park Medal of the Royal Geographical Society in 1936, the Bigsby Medal of the Geological Society in 1945 and the International Geological Congress Spendiarov Prize in 1948. He was elected to the Royal Society in 1946.

\section{New Harwell Electromagnetic Isotope Separator}

A SECOND electromagnetic isotope separation plant has been completed at the Atomic Energy Research Establishment at Harwell and the collection of separated or enriched isotopes has started. A small electromagnetic separator has been running at Harwell for two years and has been supplying samples of isotopes of light elements for nuclear physics work. The new plant is capable of separating for experimental work gram quantities of the isotopes of the heavy elements, including uranium, at a high degree of enrichment, and the first separations were carried out in May. While the large electromagnetic plant is expected to be fully occupied on work for the Establishment for some time to come, milligram samples of the lighter elements made by the smaller plant will be made available for export, as well as for use in Britain, as supplies permit. The new plant was designed by a group of scientific workers at Harwell and was manufactured by MetropolitanVickers Electrical Co., Itd., in conjunction with the General Electric Company, Ltd., and the British Thomson-Houston Co., Ltd.

\section{Marjory Stephenson Memorial Fund}

SHoRTLY after the early and much regretted death of Marjory Stephenson during her tenure of office as president of the Society for General Microbiology, it was agreed at the annual general meeting of that Society on April 20, 1949, that an appeal should be made for subscriptions from members of the Society with the view of establishing a memorial. At that time it was believed that another independent memorial was being contemplated, but this project has not materialized. In view of this the Society has decided to extend the appeal to the general public so that the very wide circle of those who admired Marjory Stephenson's work or knew her as a friend or colleague may have the opportunity to contribute. It is proposed to found a Marjory Stephenson Memorial Lecture, to be given at regular intervals, possibly annually; and in selecting the lecturer the claims of the younger members of the Society will be particularly considered. The money will be used to cover the lecturer's expenses and to present him or her with a token of the occasion in the form of a medal or books. The capital sum needed will be about $£ 1,000$. Subscriptions should be sent to the National Provincial Bank, Ltd., 12 Southwark Street, London, S.E.1, and made payable to the Society for General Microbiology, No. 2 a/c.

\section{National Institute of Sciences of India: Research Fellowships}

AT a meeting of the Council of the National Institute of Sciences of India, held on May 5, research fellowships (normally tenable for two years) were awarded to the following for work in particular fields at the places shown. National Institute of Sciences Senior Research Fellowships: S. P. Basu (physicochemical factors affecting freshwater fish culture), All-India Institute of Hygiene and Public Health, Calcutta; Dr. Sukh Dev (sesquiterpenes), Indian Institute of Science, Bangalore; Dr. P. B. Mathur (vitamin $\mathbf{C}$ in potato tubers during storage), College of Agriculture, Benares Hindu University; V. R. Thiruvenkatachar (compressible fluid flow), Central College, Bangalore. Imperial Chemical Industries (India) Research Fellowships: C. Balakrishnan (internal conversion coefficients of radioisotopes), National Physical Laboratory, New Delhi ; Dr. I. M. Chak (preparation of hæmostatics from oil-seeds), Indian Institute of Science, Bangalore; A. G. K. Menon (ichthyological studies with special reference to zoogeography), Zoological Survey of India, Calcutta; Dr. G. C. Mitra (origin and development of the leaves and their parts at the shoot apices of Angiosperms), University of Calcutta. National Institute of Sciences Junior Research Fellowships : V. Chandrasekharan (light scattering in crystals and determination of elastic constants), Indian Institute of Science, Bangalore; A. K. Chaudhuri (optics of the electron gun in electron microscopy), University of Calcutta; Dr. G. S. Deshmukh (analytical chemistry of cerium and thorium), Benares Hindu University ; Dr. B. D. Mundkur (heredity and variation in Ascomycetes, particularly fungi yielding antibiotics), University of Bombay; N. Satapati (petrology, petrochemistry and petrotectonics of the Eastern Ghats), Andhra University, Waltair; Dr. G. Venkatachalam (animal breeding, including animal genetics and applied statistics), Livestock Research Station, Hosur ; Dr. (Mrs.) Vidyavati (anatomy of Labeo rohita), University of Delhi. 